\title{
ANALISIS PENGARUH PSIKOLOGI KONSUMEN DAN ETNOSENTRISME TERHADAP MINAT BELI KONSUMEN SEPATU DI CIBADUYUT BANDUNG (STUDI KASUS KONSUMEN DIANA SHOES BANDUNG)
}

\author{
Keni Kaniawati \\ Fakultas Bisnis Manajemen, Universitas Widyatama \\ Masuk : 19-08-2019, revisi: 27-09-2019, diterima untuk diterbitkan : 27-09-2019
}

\begin{abstract}
ABSTRAK
Penelitian ini dilatarbelakangi adanya penurunan minat beli konsumen yang disebabkan karenan adanya persaingan pasar yang sangat ketat, masuknya sepatu impor dengan harga yang murah, matinya inovasi dari para pengrajin sepatu . Munculnya fenomena ini diakibatkan adanya penurunan minat beli konsumen yang diakibatkan oleh adanya pengaruh psikologi konsumen dan etnosentrisme. Peneitian ini dilakukan pada konsumen sepatu di Kota Bandung. Penelitian ini bertujuan untuk mengetahui analisis pengaruh psikologis konsumen dan etnosentrisme terhadap minat beli pelanggan sepatu di kawasan cibaduyut. Metode yang digunakan dalam penelitian ini deskriptif dan verifikatif dengan menggunakan metode survei eksplanation. Tehnik analisis yang digunakan adalah asumsi klasik, koofesien korelasi dan uji regesi linear berganda. Hasil penelitian secara deskriptif menunjukkan bahwa psikologi konsumen, etnosentrisme bergerak mulai dari cukup sampai dengan baik. Sedangkan secara verifikatif bahwa psikologis konsumen dan etnosentrisme berpengaruh positif dan signifikan baik secara parsial. Hasil penelitian secara parsial menunjukkan bahwa psikologi konsumen berpengaruh terhadap minat beli pelanggan sepatu, sedangkan Etnosentrisme berpengaruh terhadap minat beli sepatu.
\end{abstract}

Kata kunci : Psikologi konsumen, Etnosentrisme dan Minat Beli Pelanggan

\section{ABSTRACT}

This research is motivated by a decrease in consumer buying interest due to the existence of very fierce market competition, the entry of imported shoes at low prices, the death of innovations from the shoe craftsmen. The emergence of this phenomenon is caused by a decrease in consumer buying interest caused by the influence of consumer psychology and ethnocentrism. This research was conducted on shoe consumers in the city of Bandung. This study aims to determine the analysis of the psychological influence of consumers and ethnocentrism on buying interest in shoes customers in Cibaduyut. The method used in this research is descriptive and verification using the explanatory survey method. The analytical techniques used are classical assumptions, correlation coefficients and multiple linear regression tests. The results of the study descriptively indicate that consumer psychology, ethnocentrism moves from sufficient to good. While verifying that consumer psychology and ethnocentrism have positive and significant effects both partially. The results of the research partially indicate that consumer psychology influences the buying interest of shoe customers, whereas ethnocentrism influences the buying interest of shoes.

Keywords: Consumer psychology, ethnocentrism and customer buying interest

\section{PENDAHULUAN}

\section{Latar Belakang}

UMKM merupakan satu bagian penting sebagai penopang perekonomian di berbagai negara termasuk Indonesia. Peranan UMKM dalam perekonomian Indonesia adalah sangat sentral dimana tertuang dalam Undang-Undang No. 20 tahun 2008 tentang Usaha Makro, Kecil dan Menengah serta dukungan pemerintah tentang Perindustrian dimana dinyatakan perindustrian diselenggarakan untuk mewujudkan industri nasional sebagai pilar dan penggerak perekonomian nasional, membuka kesempatan kerja dan perluasan kerja, meningkatkan kemakmuran dan kesejahteraan masyarakat secara berkeadilan.Peningkatan daya saing produk UMKM salah satunya dengan standarisasi produk. Standarisasi dapat digunakan sebagai salah satu alat kebijakan pemerintah dalam menata struktur ekonomi secara lebih baik. 
Industri sepatu merupakan salah satu sektor industri yang diunggulkan dalam insdustri kreatif di Indonesia. Industri tersebut memberikan dampak yang besar dalam hal pendapatan daerah serta dapat memberikan kesempatan serta peluang bagi UMKM yang ada di Indonesia. Industri kreatif dapat berkembang jika didukung oleh masyarakat yaitu dengan cara membeli atau mengkonsumsi produk dalam negeri. Etnosentrisme konsumen menjadi salah satu faktor penentu konsumen untuk membeli produk lokal atau impor. Etnosentrisme berfungsi membantu memastikan keberlangsungan kelompok dan budaya melalui peningkatan solidaritas, konformitas, koperasi, kesetiaaan dan efektivitas. Menurut Sciffman dan Kanuck, 2008, etnosentrime konsumen adalah kecenderungan konsumen untuk menerima dan menolak bebagai produk buatan luar negeri. Berdasarkan hasil penelitian (Qing et al, 2012)kecenderungan etnosentrisme konsumen juga berperan penting dalam membentuk sikap minat beli dan keputusan pembelian. Konsumen dengan etnosentrisme yang lebih tinggi mengevaluasi produk impor yang berdampak pada perekonomian. Konsumen lebih percaya membeli produk impor yang tidak patriotik karena mengakibatkan hilangnya pekerjaaan domestik dan menyebabkan kerusakan pada perkeonomian domestik. Sedangkan konsumen yang memiliki etnosentrime rendah cenderung mengevaluasi produk impor menggunakan atribut produk dari pada country of origin produk (Shimp dan Sharma dalam Bamber et al, 2011.). Dapat disimpulkan bahwa etnosentrisme konsumen adalah kecenderungan konsumen yang sangat tinggi serta menganggap kelompok sendiri sebagai kelompok yang superior dalam menilai kelompok budaya sendiri (produk lokal) dan menilai terlalu rendah kelompok luar (produk impor). Setiap kelompok menganggap bahwa jika konsumen lebih memilih produk impor dapat mengakibatkan dampak terhadap ekonomi yaitu kerusakan pada perekonomian domestik dan dianggap memiliki sikap yang tidak patriotik terhadap kebudayaannya sendiri.

Berdasarkan data dari Kemenperin, 2016, nilai ekspor industri kulit, barang kulit dan sepatu/alas kaki mengalami penurunan dari tahun 2012 hingga tahun 2015. Hal ini disebabkan oleh efek brandminded yang mengakibatkan konsumen lebih memilih membeli produk impor yang branded dibanding membeli produk lokal. Seiring dengan adanya peningkatan pertumbuhan impor terhadap sektor industri kulit, barang kulit dan sepatu/alas kaki maka berdampak pada laju pertumbuhan industri sepatu yang ada di kota Bandung khususnya Cibaduyut sebagai sentra alas kaki. Perubahan potensi sentra industri kecil membawa dampak yang fluktuatif terhadap industri sepatu. Penurunan pasar ini disebabkan menurunya daya beli masyarakat, sehingga permintaan produk alas kaki pun ikut menurun.

Penurunan permintaan produk alas kaki diikuti pula dengan penurunan penjualan di Cibaduyut khususnya di Diana shoes. Dengan melihat data pada grafik 1.1. data penjualan Diana shoes sebagai berikut :

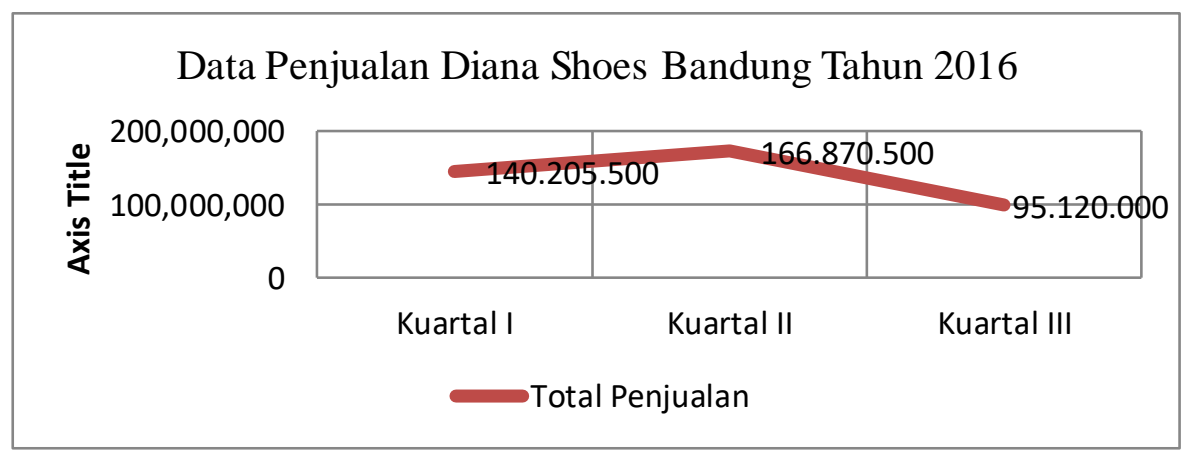

Grafik 1.1 Data Penjualan Diana Shoes Bandung

Sumber : Diana Shoes 2016, hasil data diolah 
Dari grafik 1.1. dapat kita lihat terjadi penurunan penjualan hal ini disebabkan karena terjadinya penurunan minat beli terhadap produk sepatu lokal merek Diana bahkan tidak hanya Diana Shoes hampir merata dikawasan Cibaduyut terjadi penurunan yang dratis. Hal ini juga berkaitan dengan masalah perilaku konsumen. Perilaku konsumen mengacu pada perilaku yang ditunjukkan oleh para individu dalam membeli dan menggunakan barang dan jasa.

Menurut Michael R Salomon of how individual(2009:6) perilaku konsumen dapat diartikan sebagai berikut: "A study of how individuals, groups, and organizations select, buy, use, and dispose of good, services, ideas, or experience to satisfy their need and wants." Yang berarti sebuah pembelajaran akan bagaimana sekelompok individu, beberapa grup, dan sekumpulan organisasi memilih dan membeli, menggunakan, dan membuang baik barang, jasa, ide, dan pengalaman, untuk dapat memuaskan kebutuhan dan keinginan mereka.

Berdasarkan pendapat ahli diatas, dapat disimpulkan bahwa perilaku konsumen adalah suatu tindakan yang dilakukan oleh seorang individu, kelompok, atau organisasi untuk memilih, membeli, memakai, serta memanfaatkan barang, jasa, gagasan, atau pengalaman guna memenuhi kebutuhan dan keinginan untuk menentukan kegiatannya dalam pengambilan keputusan. Dapat pula dikatakan perilaku konsumen sebuah proses dalam sistem pemasaran yang banyak dipengaruhi faktor individu dalam membuat keputusan untuk melakukan pembelian.

Psikologi konsumen berakar dari psikologi periklanan dan penjualan. Inti dari berjualan adalah membujuk dan meyakinkan orang lain untuk menerima dan melakukan hal-hal yang disampaikan oleh penjual. Motif seseorang untuk membeli barang dan jasa yang ditawarkan sangat bervariasi. Biasanya sulit untuk mengetahui motif yang sesungguhnya, ada beberapa motif menurut seorang psikolog Vanve Packard dimana kebanyakan pembelian berkisar antara mencari kekayaan dan pangkat. Di dalam kegiatan menjual membeli sering terjadi perbedaan persepsi. Untuk mengimplementasikan persepsi dilakukan beberapa hal yang meliputi : tujuan pemberian informasi, tugas dalam penyampaian informasi, metode komunikasi, alat-alat yang digunakan, cara-cara penyampaian, informasi, wadah atau organisasi dan personil, lokasi dan tempat operasi, waktu dan lamnya pelaksanaan, penanganan hambatan yang mungkin timbul, sistem pengawasan dan pengendalian. Tingkah laku komsumen banyak dipengaruhi oleh karateristik-karateristik seperti jenis kelamin, usia, watak, status, sosial ekonomi serta lokasi.

Psikologi konsumen merupakan tingkah laku atau perilaku seseorang yang didorong oleh jiwa atau mental itu sendiri dalam melakukan aktivitas yang diinginkannya. Psikologi konsumen juga dapat diartikan sebagai perubahan perilaku manusia dalam menggunakan produk atau jasa yang dipasarkan. Menurut Kotler dan Amstrong (2012:215) bahwa psikologi konsumen itu dipengaruhi oleh empat faktor utama diantaranya: motivasi,pembelajaran, persepsi, keyakinan dan sikap. Motivasi pelanggan diukur dengan tingkat pemenuhan kebutuhan, pemenuhan keinginan, ekspresi diri, dorongan iternal dan dorongan eksternal. Persepsi pelanggan diukur dengan pengalaman masa lalu, kesesuaian harapan, selektifitas pelanggan, dan persepsi terhadap iklan perusahaan. Pengetahuan pelanggan ukurannya adalah pengetahuan terhadap kualitas, pengetahuan terhadap produk dan pengetahuan terhadap merek. Sikap dan keyakinan ukurannya adalah gagasan, perasaan, keinginan dan kepercayaan .

Dewasa ini masalah pemasaran merupakan masalah yang sangat dominan dalam menghadapi persaingan di pasar saat ini. Kompetisi yang bergerak cepat mengharuskan perusahaan memiliki strategi yang tepat dalam memasarkan produknya. Apalagi dengan turunya minat beli konsumen terhadap produk sepatu dikawasan Cibaduyut memacu para pengusaha sepatun untuk lebih memperhatikan kebutuhan konsumen saat ini dengan cara memahami psikologi konsumen dan etnosentrisme konsumen. 
Minat beli konsumen menurut Durianto (2013:58) adalah keinginan untuk memiliki produk, minat beli akan timbul apabila seseorang konsumen sudah terpengaruh terhadap mutu dan kualitas dari suatu produk, informasi seputar produk seperti harga, cara membeli dan kelemahan serta keunggulan produk dibandingkan dengan merek lain. Sedangkan menurut Monroe dan Grewal (1991) minat beli konsumen yaitu "Purchase intention comes into consideration when a customer is probably attemption to buy some product or services." Artinya Minat beli datang ke dalam pertimbangan seseorang ketika seorang pelanggan akan mencoba untuk membeli beberapa produk atau jasa yang dibutuhkan". Menurut Phillip Kotler dan Kevin Lane Keller (2012) pada minat beli terdapat beberapa tahapan yaitu dengan konsep AIDA diantaranya menaruh perhatian terhadap barang dan jasa (attention), bila berkesan maka melangkah kepada ketertarikan (interest), untuk lebih dalam mengetahui keistimewaan produk tersebut. Apabila intensitas ketertarikannya sangat tinggi, maka akan bergeser ke tahap desire (minat atau berhasrat). Dan apabila hasrat atau minatnya begitu tinggi, baik karena dorongan dari dalam suatu rangsangan persuasif dari luar, maka konsumen atau pembeli akan mengambil keputusan atas penawaran tersebut dimana disini memiliki kematangan untuk membeli atau menggunakan produk yang ditawarkan (action to buy).

Dari definisi diatas, maka dapat disimpulkan bahwa minat beli adalah keinginan calon pembeli untuk memiliki atau membeli produk atau jasa yang dibutuhkan dengan mempertimbangkan terlebih dahulu kelebihan serta kekurangan dari produk atau jasa tersebut dengan produk lain. Jika calon pembeli telah mengetahui informasi mengenai produk atau jasa tersebut maka calon pembeli akan melakukan keputusan pembelian untuk menumbuhkan minat beli terhadap produk atau jasa yang diinginkan oleh calon pembeli.

Pada penelitian ini peneliti menemukan adanya penurunan minat beli pelanggan terhadap produk sepatu di kawasan Cibaduyut khususnya di Diana Shoes berdasarkan data dari tahun $2013 \mathrm{~s} / \mathrm{d}$ 2017 . Faktor penyebab terjadinya penurunan minat beli ini berdampak pada turunnya penjualan disebabkan karena beberapa hal yaitu : 1). Persaingan yang semakin ketat, masuknya produk sepatu impor dengan model yang lebih variatif dan kualitas yang bagus, harga yang lebih murah dari sepatu lokal. Hal ini juga disebabkan karena mindset calon konsumen terhadap produk sepatu impor lebih baik dibandingkan dengan sepatu lokal. 2). Berdasarkan observasi dilapangan, responden mencintai produk sepatu lokal, tetapi sebagian besar membeli produk sepatu impor yang berakibat matinya kreatifitas dan inovasi para pengrajin sepatu dikawasan Cibaduyut dan berdampak pada beberapa toko di kawasan tersebut menjadi sepi pelanggan. Sebagian besar konsumen beralih membeli produk sepatu impor.

\section{Rumusan Masalah}

Berdasarkan latar belakang penelitian, maka peneliti dapat merumuskan beberapa masalah yaitu :

1. Bagaimana Etnosentrisme konsumen pada produk sepatu lokal di Diana shoes.

2. Bagaimana Psikologi Konsumen pada produk sepatu lokal di Diana shoes.

3. Bagaimana minat beli konsumen pada produk sepatu lokal di Diana shoes.

4. Seberapa besar pengaruh Etnosentrisme dan psikologi konsumen terhadap produk sepatu lokal di Diana shoes.

\section{METODE PENELITIAN}

Metode penelitian yang digunakan dalam penelitian in adalah metode desciptive survey dan explanatory survey. Menurut Sugioyono (2016:92) Descriptive survey dilakukan untuk mendapatkan gambaran tentang variabel yang diteliti. Sedangkan explanatory untuk memperoleh gambaran keterkaitan sebab akibat antar variabel yang diteliti melalui pengujian hipotesis berdasarkan data yang diperoleh di lapangan. Adapun jenis penelitianb yang digunakan adalah 
deskriptif-verifikatif, maksudnya peneliti berusaha menguji jawaban masalah yang kebenaranya bersifat sementara berdasarkan data empiris. Metode deskriptive-verifikatif digunakan untuk menguji apakah etnosentrisme dan psikologi konsumen berpengaruh terhadap minat beli produk sepatu lokal di kawasan Cibaduyut Bandung khususnya di Diana Shoes.

Populasi dalam penelitian ini adalah seluruh pengunjung Diana shoes selama tiga bulan yaitu 245 orang. Dengan menggunakan tehnik rumus Slovin (Listyorini:2012) maka jumlah sampel minimal yang dapat digunakan dalam penelitian ini ditetapkan dengan $\alpha=0,05$ (derajat kepercayaan 95\%). Maka dalam penelitian ini ditentukan bahwa sampel yang akan diteliti sebanyak 152 responden pengunjung yang membeli produk sepatu lokal di Diana Shoes. Metode analisis yang digunakan dalam penelitian ini adalah uji linier berganda, uji asumsi klasik, analisis kooefesien korelasi, koofesien diterminasi dan uji hipotesis. Untuk menguji apakah variabel etnosentrisme konsumen dan psikologi konsumen berpengaruh terhadap minat beli produk sepatu lokal di Diana Shoes. Adapun pengujian hipotesis secara parsial adalah sebagai berikut:

1). Hipotesis pertama

$\mathrm{H}_{0}$ : $\rho y x_{1}=0$; Tidak terdapat pengaruh etnosentrisme konsumen terhadap minat beli produk sepatu lokal di Diana Shoes

$\mathrm{H}_{1}: \rho y x_{1} \neq 0$; Terdapat pengaruh etnosentrisme konsumen terhadap minat beli produk sepatu lokal di Diana Shoes.

2). Hipotesis kedua

$\mathrm{H}_{0}: \rho y x_{2}=0$; Tidak terdapat pengaruh psikologi konsumen terhadap minat beli produk sepatu lokal di Diana Shoes

$\mathrm{H}_{1}: \rho y x_{2} \neq 0$; Terdapat pengaruh psikologi konsumen terhadap minat beli produk sepatu lokal di Diana Shoes.

\section{HASIL DAN PEMBAHASAN \\ Analisis Koefisien Korelasi Pearson}

Tabel 3.1

Hasil Analisis Uji Korelasi Variabel $\mathrm{X}_{1}$

(Etnosentrisme terhadap Minat Beli) Correlations

Sumber : data yang diolah di SPSS

\begin{tabular}{cccc}
\hline Etnosentrisme & $\begin{array}{c}\text { Pearson } \\
\text { Correlation }\end{array}$ & Etnosentrisme & Minat Beli \\
\hline & Sig. (2-tailed) & 1 & .410 \\
\hline & $\mathrm{N}$ & 152 & .000 \\
\hline \multirow{4}{*}{ Minat Beli } & $\begin{array}{c}\text { Pearson } \\
\text { Correlation }\end{array}$ & .410 & 152 \\
\hline & Sig. (2-tailed) & .000 & \\
\hline & $\mathrm{N}$ & 152 \\
\hline
\end{tabular}

Dilihat pada tabel 3.1 diatas, hubungan variabel $\left(\mathrm{X}_{1)}\right.$ terhadap variabel $(\mathrm{Y})$ sebesar 0,410 . Hasil dari Uji Korelasi memiliki hubungan yang antara variabel $\left(\mathrm{X}_{1}\right)$ Etnosentrisme dan variabel (Y) Minat Beli yaitu dengan koefisien korelasi sebesar 0,410. Hal ini menunjukan terdapat hubungan yang signifikan $(<0,05)$ diantara Etnosentrisme terhadap Minat Beli. Serta dapat dikatakan sedang karena berada pada interval $0.40-0.599$ dan searah karena bernilai positif (+). 
Tabel 3.2

Hasil Analisis Uji Korelasi Variabel $\mathrm{X}_{2}$ (Psikologi Konsumen terhadap Minat Beli) Correlations

\begin{tabular}{|c|c|c|}
\hline $\begin{array}{l}\text { Psikologi } \\
\text { Konsumen }\end{array}$ & & Isumen \\
\hline & Pearson Correlation & 1 \\
\hline & Sig. (2-tailed) & \\
\hline & $\mathrm{N}$ & 152 \\
\hline Minat Beli & Pearson Correlation & $.812 * *$ \\
\hline
\end{tabular}

Dari hasil pengolahan data menggunakan SPSS, dapat dilihat pada tabel diatas, hasil dari uji korelasi memiliki hubungan yang antara variabel $\left(\mathrm{X}_{2}\right)$ Psikologi konsumen dan variabel (Y) Minat Beli yaitu dengan koefisien korelasi sebesar 0,812. Hal ini menunjukan terdapat hubungan yang signifikan $(<0,05)$ diantara psikologi konsumen terhadap Minat Beli. Serta dapat dikatakan memiliki hubungan yang sangat kuat karena berada pada interval $0.80-1.000$ dan searah karena bernilai positif $(+)$.

\section{Koefisien Determinasi}

Koefisien determinasi bertujuan untuk mengukur seberapa besar keterikatan atau keeratan variabel, antara variabel dependen (Minat Beli) dengan variabel independen (Etnosentrisme dan psikologi konsumen). Maka digunakan perhitungan koefisien determinasi sebesar 16, 12\%. Jadi, dapat disimpulkan bahwa variabel (X1) Etnosentrisme mempengaruhi variabel (Y) Minat Beli sebesar $16,12 \%$ sedangkan sisanya sebesar $(100 \%-16.12 \%)=83,88 \%$ dipengaruhi oleh variabel lain yang tidak diteliti dalam penelitian ini. Koefisien determinasi $\mathrm{X}_{2} \mathrm{ke} \mathrm{Y}$ sebesar $65,45 \%$. Jadi, dapat disimpulkan bahwa variabel $\left(\mathrm{X}_{2}\right)$ Psikologi konsumen mempengaruhi variabel (Y) Minat Beli sebesar $65,45 \%$ sedangkan sisanya sebesar $(100 \%-65,45 \%)=34,55 \%$ dipengaruhi oleh variabel lain yang tidak diteliti dalam penelitian ini.

\section{Uji Regresi Linier Berganda}

Model regresi adalah model yang digunakan untuk menganalisis pengaruh dari berbagai variabel independen variabel $\mathrm{X}_{1}$ (Etnosentrisme), $\mathrm{X}_{2}$ (psikologis konsumen) terhadap satu variabel dependen Y (Minat Beli). Berdasarkan hasil perhitungan menggunakan software SPSS 23.0, diperoleh hasil sebagai berikut :

Tabel 4.24

Hasil Analisis Uji Regresi Linier Berganda

Coefficients $^{\mathrm{a}}$

\begin{tabular}{lllllll} 
Model & & \multicolumn{2}{l}{$\begin{array}{l}\text { Unstandardized } \\
\text { Coefficients }\end{array}$} & $\begin{array}{l}\text { Standardized } \\
\text { Coefficients }\end{array}$ & T & Sig. \\
\hline & & B & Std. Error & Beta & & \\
\hline 1 & (Constant) & .325 & .166 & & 1.629 & .075 \\
\hline & Etnosentrisme & .134 & .051 & .112 & 2.215 & .013 \\
\hline & & & & & 14.32 & \\
& Psikologi Konsumen & .805 & .040 & .754 & 3 & .000 \\
\hline
\end{tabular}




$$
\gamma=0.325+0.134+0.805+e
$$

Berdasarkan hasil perhitungan menggunakan software SPSS 23.0, diperoleh hasil sebagai berikut :

1. Jika nilai variabel $X_{1}$ dan $X_{2}$ sama dengan (0) maka nilai dari variabel $Y=0,325$.

2. Jika nilai variabel $X_{1}$ dan $X 2$ masing-masing naik sebesar 1, maka nilai variabel $Y$ akan mengalami kenaikan sebesar $(Y=0.325+0.134(1)+0.805(1))=1.264$

\section{Pengujian Uji Hipotesis}

Menurut Ghozali (2011 :160), uji t pada dasarnya menunjukkan seberapa jauh pengaruh satu variabel independen secara individual dalam menerangkan variabel dependen. Berikut hasil uji $\mathrm{T}$ pada tabel - tabel berikut :

Tabel 4.25

Uji t

Sumber : data yang diolah di SPSS

Coefficients $^{\mathrm{a}}$

\begin{tabular}{|c|c|c|c|c|c|}
\hline \multirow[t]{2}{*}{ Model } & & Unst & ardized Coefficients & $\begin{array}{l}\text { Standardized } \\
\text { Coefficients }\end{array}$ & $\mathrm{t}$ \\
\hline & & $\mathrm{B}$ & Std. Error & Beta & \\
\hline 1 & (Constant) & .325 & .166 & & 1.629 \\
\hline & Etnosentrisme & .134 & .051 & . 112 & 2.215 \\
\hline & $\begin{array}{l}\text { Psikologi } \\
\text { konsumen }\end{array}$ & .805 & .040 & .754 & 14.323 \\
\hline
\end{tabular}

a. Dependent Variable: Minat Beli

Hasil uji hipotesis dengan menggunakan uji $\mathrm{t}$ (parsial) diperoleh $\mathrm{t}_{\text {hitung }} \geq \mathrm{t}_{\text {tabel }}=14.323 \geq 1,629$. Dengan demikian $\mathrm{H}_{0}$ ditolak dan $\mathrm{H}_{1}$ diterima. Maka secara parsial Psikologi Konsumen berpengaruh terhadap Minat Beli Produk Sepatu Lokal di Diana Shoes.

\section{KESIMPULAN DAN SARAN}

Hasil penelitian ini dapat disimpulkan sebagai berikut :1). Etnosentrisme berpengaruh signifikan terhadap minat beli konsumen. Berdasarkan hasil ini hipotesis pertama penelitian (H1) yang menduga etnosentrisme berpengaruh terhadap minat beli konsumen telah terbukti kebenarannya. 2). Psikologi konsumen berpengaruh signifikan terhadap minat beli konsumen. Berdasarkan hasil ini hipotesis kedua penelitian (H2) yang menduga psikologi konsumen berpengaruh terhadap minat beli konsumen telah terbukti kebenarannya. 3).Etnosentrisme dan psikologi konsumeen bersaman berpengaruh terhadap minat beli konsumen telah terbukti kebenarannya. Sedangkan saran yang dapat berikan dari peneliti yaitu : 1). Diana Shoes sebagai produsen sepatu lokal di Kota Bandung sebaiknya mengajak para pengunjung yaitu calon konsumen agar menggunakan produk sepatu lokal yaitu produk sepatu Diana karena dari hal terkecil tersebut, secara tidak langsung dapat mencerminkan sifat etnosentrisme konsumen yang tinggi, membantu menstabilkan perekonomian Indonesia dan mencerminkan rasa nasionalisme kepada negara. Selain itu, dengan menggunakan produk sepatu lokal dapat menunjukkan kepada negara lain bahwa produk lokal tidak kalah saing dengan produk asing.2).Guna meningkatkan psikologikonsumen, Diana Shoes harus cepat tanggap dalam merespon kebutuhan konsumen, harga jangan terlampau tinggi dan memberikanjaminan terhadap standar mutu produk sepatu yang dihasilkan. 


\section{ACKNOWLEDGEMENT}

Peneliti mengucapkan terimakasih kepada Universitas Widyatama yang telah memfasilitasi terlaksananya penelitian ini. Dan juga mengucapkan terimaksih banyak kepada Universitas Tarumanegara Jakarta yang telah memberikan kesempatan untuk mempresentasikan di Seminar nasional Riset multidisplin 2019 dan di publish pada jurnal UNTAR.

\section{REFERENSI}

Durianto, Darmadi, Sugiarto dan Tony Sitinjak. 2013. Strategi Menaklukkan Pasar Melalui Riset Ekuitas dan Perilaku Merek. Cetakan Ketiga. Jakarta: Gramedia Pustaka Utama.

Et al, Qing. 2012. The Impact of lifestyle and ethnocentrism on customers' purchase intentions of fresh fruit in China. www. emeraldinsight.com. 2 Juni 2016

Gillani. 2012. Efektivitas iklan TV, asosiasi merek, dan kelompok referensi terhadap minat beli susu bubuk L-men di Kota Semarang.

Ghozali, Iman 2013. Aplikasi Analisis Multivariat Dengan Program SPSS, Semarang.badan penerbit Universitas Diponegoro.

Kotler, Philip and Kevin Lane Keller. 2012. Marketing Management 13. New Jersey :Pearson Prentice Hall, Inc.

Kotler, Phillip and Gary Amstrong. 2012. Prinsip-Prinsip Pemasaran. Edisi 13. Jilid 1. Jakarta: Erlangga

Kemenperin.go.id.2016, tentang Industri Alas kaki., Brand and Store information on Buyers Product evaluations

Monroe Kent and Grewal Dhruv, In Journal Marketing Research "Effect of Price Brand and Store Information on Buyers Product Evaluations. 1991

Schiffman, Leon dan Kanuk, Leslie Lazar. 2012. Perilaku Konsumen Edisi 7 Cetakan Kedua. Jakarta: Indeks.

Shimp, T.A. and Sharma, S. 2011, Consumer ethnocentrism: construction and validation of the CETSCALE. Journal of Marketing Research, Vol. 27, pp.280- 289.

Solomon, M.R. \& Rabolt, N. 2009. Consumer Behaviour In Fashion, $2^{\text {nd }}$ Edition. USA :Prentice Hall. Sunyoto,

Sugiyono. 2016. Metode Penelitian (Pendekatan Kuantitatif, Kualitatif, dan R\&D). Bandung : Alfabeta.

Undang-Undang No.20 tahun 2008 Tentang Usaha Mengengak kecil Mikro 